\title{
Conducting tissue of the heart in kwashiorkor
}

\author{
B. A. Sims \\ From the Department of Pathology, Queen's University of Belfast
}

The conducting tissue of the heart was examined histologically in 7 cases of kwashiorkor. Atrophic changes were found, and in 5 cases myocytolysis was present. No cellular reaction or fibrous repair was found in relation to the areas of myocytolysis. These findings may be associated with a disturbance of atrioventricular conduction during life, perhaps accounting for some of the unexplained sudden deaths occurring in children with kwashiorkor.

There is now considerable evidence to suggest that the heart is involved in kwashiorkor. Gopalan (1955) reported electrocardiographic abnormalities such as bradycardia, $T$ wave changes, and a prolonged QT interval, while histologically there was atrophy of the cardiac muscle fibres. A special study of the heart in kwashiorkor was made by Smythe, Swanepoel, and Campbell (1962) in which they analysed the electrocardiogram to find $T$ wave inversion and a prolonged QT interval. Histological examination in 24 cases revealed vacuolation of the muscle fibres and some oedema between the cells. They considered that these findings might account for some of the sudden deaths, and also the low cardiac output state found in kwashiorkor. This study was undertaken to exclude an abnormality involving the conducting tissue of the heart in this condition.

\section{Material and method}

The clinical details and the pathological material of 7 children with kwashiorkor were supplied by the Department of Pathology, Makerere University College, Kampala, Uganda, which made this study possible. Five cases of similar age with normal nutrition were also studied for comparison.

The atrioventricular conducting tissue was examined histologically using the technique described by Hudson (1965). Sections from the different parts of the conducting tissue were studied in cases of kwashiorkor and also in cases with normal nutrition, without a knowledge of the clinical background. Later the findings of the histological examination were compared.

\section{Results}

The clinical, pathological, and histological abnormalities are presented in the Table.

\footnotetext{
Received 25 November 1971.
}

The children in the 7 cases were aged $I$ to 3 years, showing skin changes and oedema characteristic of kwashiorkor in most instances. The commonest cause of death was a respiratory infection.

Histological examination of the myocardium shows the muscle fibres to be atrophic but no degenerative change is evident. In the conducting tissue the wasting of the fibres is more obvious. They contain vacuoles and are surrounded by interstitial oedema as shown in the Fig. In areas the vacuolation is extensive when it appears that myocytolysis has occurred. This change is seen in varying

FIG. There is wasting of the conducting fibres in the AV bundle with interstitial oedema.

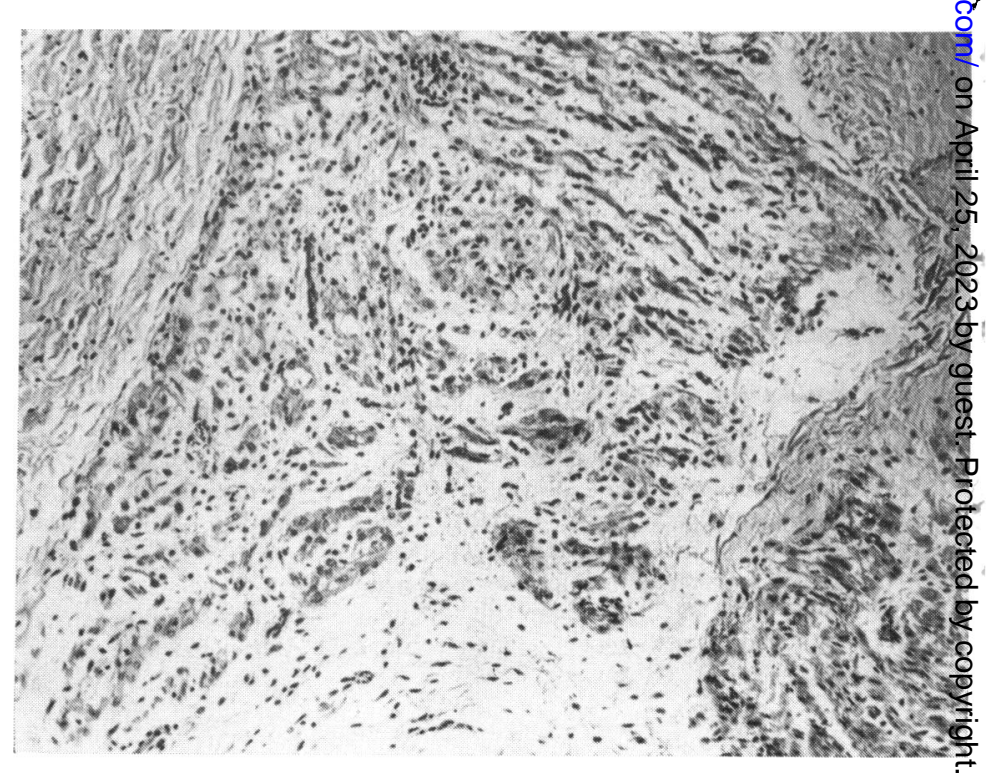


I ABLE Clinical and pathological findings in cases of kwashiorkor

\begin{tabular}{|c|c|c|c|c|c|}
\hline $\begin{array}{l}\text { Case } \\
\text { No. }\end{array}$ & $\begin{array}{l}\text { Ag } \\
\text { and }\end{array}$ & & Clinical findings & Pathological diagnosis & $\begin{array}{l}\text { Histological findings } \\
\text { in conducting tissue }\end{array}$ \\
\hline $\mathbf{I}$ & $2 \frac{1}{2}$ & $\mathbf{M}$ & Skin rash and oedema & $\begin{array}{l}\text { Kwashiorkor; oedema lungs, } \\
\text { ? viral pneumonia }\end{array}$ & 一 \\
\hline 2 & $\mathbf{I}$ & $\mathbf{F}$ & $\begin{array}{l}\text { Diarrhoea and vomiting; } \\
\text { anaemia; skin ulcers }\end{array}$ & $\begin{array}{l}\text { Kwashiorkor; anaemia; pneu- } \\
\text { monia }\end{array}$ & $\begin{array}{l}\text { Myolysis in AV node } \\
\text { and main bundle }\end{array}$ \\
\hline 3 & $\mathbf{I}$ & $\mathbf{F}$ & $\begin{array}{l}\text { Diarrhoea and vomiting; de- } \\
\text { pigmentation of skin; oedema }\end{array}$ & Kwashiorkor; pneumonia & $\begin{array}{l}\text { Myolysis in bundle } \\
\text { and branches }\end{array}$ \\
\hline 4 & $2 \frac{3}{4}$ & $\mathbf{M}$ & Oedema; heart failure & $\begin{array}{l}\text { Kwashiorkor; viral pneumonia; } \\
\text { malaria }\end{array}$ & $\begin{array}{l}\text { Myolysis in AV node } \\
\text { and bundle }\end{array}$ \\
\hline 5 & 3 & $\mathbf{F}$ & Diarrhoea and vomiting; oedema & $\begin{array}{l}\text { Kwashiorkor; pneumonia; hook- } \\
\text { worms }\end{array}$ & 一 \\
\hline 6 & $\mathbf{I}$ & $\mathbf{M}$ & $\begin{array}{l}\text { Diarrhoea; wasted; depigmenta- } \\
\text { tion of skin }\end{array}$ & $\begin{array}{l}\text { Kwashiorkor; broncho- } \\
\text { pneumonia; malaria }\end{array}$ & $\begin{array}{l}\text { Myolysis in all parts } \\
\text { of tissue }\end{array}$ \\
\hline 7 & 2 & $\mathbf{M}$ & $\begin{array}{l}\text { Vomiting and diarrhoea; oedema; } \\
\text { palpable liver }\end{array}$ & $\begin{array}{l}\text { Kwashiorkor; malabsorption } \\
\text { ? lactose intolerance; } \\
\text { loss of pancreatic tissue }\end{array}$ & Myolysis in AV node \\
\hline
\end{tabular}

severity in 5 cases. In none of these cases are inflammatory cells or Anitschkow myocytes seen in relation to areas of myocytolysis. Also no increase in connective tissue is present in these areas. No such changes are present in the control cases with normal nutrition.

\section{Discussion}

The most striking histological finding in the conducting tissue in these cases of kwashiorkor is the wasting and disintegration of conducting fibres. The term myocytolysis is used to describe the latter process which is similar to the change of myolysis described by Chauhan, Nayak, and Ramalingaswami (1965) in protein deficient rhesus monkeys. The resulting clear areas may represent interstitial cedema but no fibrosis has occurred.

Wharton et al. (1969) examined the myotardium histologically in 5 cases of kwashiorkor, and in $\mathbf{2}$ found areas of patchy necrosis in the papillary muscles and subendocardially. In I case in the present series myocytolysis is involving the left bundle-branch as it lies under the endocardium, but no areas of necrosis are seen in the myocardium.

- This study has shown atrophic changes in the conducting tissue with kwashiorkor, the functional significance of which is uncertain, but they may produce a failure of atrioventricular conduction to cause sudden death. The more conspicuous atrophic changes in the conducting tissue suggest that it is more sensitive to protein deficiency than the ordinary myocardial fibres, perhaps because the conducting fibres contain fewer myofibrils.

I am grateful to Professor M. S. R. Hutt and his staff in the Pathology Department, Makerere University College, Kampala, Uganda, for supplying the clinical details and the pathological specimens. Also to Professor Sir John Biggart, C.B.E., in whose department this study was performed. I am also indebted to Dr. D. R. Hadden for his advice and encouragement, to Professor Florence McKeown for her assistance with the histology, and to Mr. W. Kirkwood for the technical assistance in preparing the histological sections.

\section{References}

Chauhan, S., Nayak, N. C., and Ramalingaswami, V. (1965). The heart and skeletal muscle in experimental protein malnutrition in rhesus monkeys. fournal of Pathology and Bacteriology, 90, 30r.

Gopalan, C. (1955). In Discussion on pathology of protein malnutrition. In Protein Malnutrition, p. I27. Ed. by J. C. Waterlow. University Press, Cambridge.

Hudson, R. E. B. (1965). Cardiovascular Pathology, Vol. I, p. 66. Edward Arnold, London.

Smythe, P. M., Swanepoel, A., and Campbell, J. A. H. (1962). The heart in kwashiorkor. British Medical fournal, $1,67$.

Wharton, B. A., Balmer, S. E., Somers, K., and Templeton, A. C. (1969). The myocardium in kwashiorkor. Quarterly fournal of Medicine, 38, I07.

Requests for reprints to Dr. B. A. Sims, Department of Therapeutics and Pharmacology, Institute of Clinical Science, Grosvenor Road, Belfast, BTI2 6BJ, Northern Ireland. 